Témoigner Témoigner. Entre histoire et mémoire

Getuigen Revue pluridisciplinaire de la Fondation Auschwitz

$115 \mid 2013$

L'Espagne en construction mémorielle

\title{
Rondom genocide - of hoe het schijnbaar objectieve toch het subjectieve weerspiegelt
}

Autour du génocide - ou comment l'objectivité apparente reflète toujours le subjectif

On genocide or: How apparent objectivity conceals in fact a subjective viewpoint

Fabian Van Samang

\section{(2) OpenEdition}

Journals

Édition électronique

URL : https://journals.openedition.org/temoigner/551

DOI : 10.4000/temoigner.551

ISSN : 2506-6390

Éditeur :

Éditions du Centre d'études et de documentation Mémoire d'Auschwitz, Éditions Kimé

Édition imprimée

Date de publication : 1 mars 2013

Pagination : 149-163

ISBN : 978-2-84174-628-6

ISSN : 2031-4183

Référence électronique

Fabian Van Samang, «Rondom genocide - of hoe het schijnbaar objectieve toch het subjectieve weerspiegelt», Témoigner. Entre histoire et mémoire [Online], 115 | 2013, Online op 01 juin 2015, geraadpleegd op 03 février 2022. URL: http://journals.openedition.org/temoigner/551 ; DOI: https:// doi.org/10.4000/temoigner.551 


\title{
Rondom genocide - of hoe het schijnbaar objectieve toch het subjectieve weerspiegelt
}

\author{
DR. FABIAN VAN SAMANG
}

Historicus

\section{INLEIDING}

Zelfs met het groeiende aanbod van informatie op het wereldwijde web, lijkt het raadplegen van encyclopedia nog steeds de eerste stap bij het opsporen van betrouwbare gegevens over historische gebeurtenissen. De auteurs van encyclopedieartikelen, zo luidt het, zijn immers vaak experten in hun vakgebied - wetenschappers met aanzien die het zich niet kunnen veroorloven om in duurzame media grove fouten te laten binnensluipen. Het voortdurende nazicht door het grote publiek én hun collega's professoren staat bovendien garant voor een maximale objectiviteit. Dit steekt fel af tegen de grote anonimiteit en partijdigheid waardoor tal van websites vandaag zouden worden gekenmerkt. Bovendien, zo gaat het argument verder, zijn de informatiebronnen van de auteurs eenvoudig na te trekken. Ze staan vaak onderaan de bijdrage in afwijkend lettertype vermeld, waardoor de mogelijkheid tot controle zich opent én een aanknopingspunt voor verder, meer diepgaand onderzoek wordt aangereikt.

In dit artikel worden deze assumpties getoetst. De inhoudelijke analyse van encyclopedia, waarin het lemma 'genocide' aan bod komt, kan meer duidelijkheid verschaffen over de achtergrond en de deskundigheid van de auteurs, de objectiviteit en juistheid van het artikel en de controleerbaarheid van de weergegeven informatiebronnen. Die encyclopedia werden verzameld inéén universiteitsbibliotheek (KU Leuven: de Centrale Bibliotheek, de bibliotheek van de Rechtenfaculteit en van de faculteit Sociale Wetenschappen), één stadsbibliotheek (Stadsbibliotheek Brugge) en één schoolbibliotheek (Klein Seminarie Roeselare). In totaal werden daar 35 algemene en gespecialiseerde encyclopedia aangetroffen (zie tabel 1). Op basis van dit bronnencorpus kon een antwoord worden gezocht op de voorliggende onderzoeksvragen. Zijn encyclopedia (nog steeds) de aangewezen eerste stap in het 
Tabel 1: Geraadpleegde encyclopedia (chronologisch).

\begin{tabular}{|c|c|c|c|c|}
\hline Auteur & Encyclopedie & Deel & Jaar & Pagina's \\
\hline Janssens, L. & De katholieke encyclopedie & $\mathrm{IX}$ & 1951 & $539-540$ \\
\hline Palazzini, Pietro. & Enciclopedia Cattolica & $\mathrm{VI}$ & 1951 & $16-20$ \\
\hline Anoniem, & Der Grosse Herder & III & 1953 & 1504 \\
\hline Anoniem, & Dizionario Enciclopedico Italiano & $\mathrm{V}$ & 1956 & 273 \\
\hline Anoniem, & Oosthoeks Encyclopedie & $\mathrm{Vl}$ & 1961 & 238 \\
\hline Anoniem, & Grand Larousse Encyclopédique & V & 1962 & 431 \\
\hline O'Brien, William, & New catholic encyclopedia & $\mathrm{Vl}$ & 1967 & $336-337$ \\
\hline Anoniem, & Standaard Encyclopedie. & $\mathrm{VI}$ & 1968 & $55-56$ \\
\hline Anoniem, & Dictionnaire encyclopédique Quillet & IV & 1969 & 2754 \\
\hline Robinson, N. & Encyclopaedia Judaica & VII & 1971 & $409-410$ \\
\hline Anoniem, & Encyclopedia Lituanica & II & 1972 & $300-301$ \\
\hline De La Pradelle, Paul & La Grande Encyclopédie Larousse & IX & 1974 & 5362 \\
\hline Anoniem, & Diccionario enciclopédico abreviado & IV & 1974 & $345-346$ \\
\hline Anoniem, & Great Soviet Encyclopedia & VII & 1975 & 192 \\
\hline Anoniem, & Enciclopedia Europaea & $\mathrm{V}$ & 1977 & 282 \\
\hline Anoniem, & De Grote Oosthoek & VIII & 1978 & 197-198 \\
\hline Anoniem, & Meyers Enzyklopädisches Lexikon, & XXIV & 1979 & $665-666$ \\
\hline Anoniem, & $\begin{array}{l}\text { Grote Winkler Prins. Encyclopedie } \\
\text { in } 25 \text { delen }\end{array}$ & $\mathrm{IX}$ & 1980 & 414 \\
\hline Ortego Costales, J & Gran Enciclopedia Rialp & $x$ & 1987 & $779-780$ \\
\hline Anoniem, & Encyclopedia of Ukraine & II & 1988 & $27-28$ \\
\hline Anoniem, & $\begin{array}{l}\text { Grote Winkler Prins. Encyclopedie } \\
\text { in } 25 \text { delen }\end{array}$ & IX & 1991 & $564-565$ \\
\hline Deng, $\mathrm{F}$. & $\begin{array}{l}\text { Encyclopedia of Africa south } \\
\text { of the Sahara }\end{array}$ & II & 1997 & $207-214$ \\
\hline Allcock, J. & $\begin{array}{l}\text { Conflict in the Former Yugoslavia. } \\
\text { An Encyclopedia }\end{array}$ & I & 1998 & $99-100$ \\
\hline Lang, Berel & Encyclopedia of Ethics & 1 & 2001 & $607-608$ \\
\hline Vasak, Karel & Encyclopaedia Universalis & $x$ & 2002 & $140-141$ \\
\hline Brannigan en Cassis & Encyclopedia of crime and punishment & II & 2002 & $769-776$ \\
\hline Anoniem, & Encyclopedie van de Holocaust & 1 & 2003 & $231-232$ \\
\hline Greppi, Edouardo & L’Enciclopedia & IX & 2003 & $137-138$ \\
\hline Libaridian, Gerard. & Encyclopedia of Russian History & II & 2004 & $544-545$ \\
\hline Andreopoulos, G. & The New Encyclopaedia Britannica & V & 2005 & 183 \\
\hline Welch, Claude. & Encyclopedia Americana & XII & 2006 & 424 \\
\hline Anoniem, & Brockhaus Enzyklopädie & XXIX & 2006 & 189 \\
\hline Robinson, Nehemiah. & Encyclopedia Judaica & VII & 2007 & 484-485 \\
\hline Bronkhorst, Daan & Encyclopedie van de menselijkheid & I & 2007 & $139-140$ \\
\hline Schabas, William & Encyclopedia of Human Rights & II & 2009 & $294-304$ \\
\hline
\end{tabular}


heuristische onderzoek? Zijn ze dat ooit geweest? Geven ze een - door de beperkte omvang van de bijdrage altijd ongenuanceerd, maar toch - helder beeld van het omschreven begrip? Of vindt men in het objectieve verhaal ook elementen van partijdigheid, persoonlijke voorkeuren en betwistbare stellingen terug?

\section{DE AUTEURS EN HUN ACHTERGRONDEN}

In tegenstelling tot de heersende opvatting, dat bij het opduiken van flagrante fouten een auteur op zijn tekortkomingen kan worden gewezen, blijven encyclopedia hierin vaak in gebreke. Bij zeventien van de vijfendertig artikelen wordt immers geen auteur vermeld. Dit is voornamelijk het geval bij de kortere artikelen, waarin hoe dan ook al minder ruimte is voor nuance. Daar waar het land van herkomst bij 14 van de 17 identificeerbare auteurs (twee artikelen werden door dezelfde auteur geschreven) erg uiteenlopend is (naast drie Amerikanen, twee Nederlanders, twee Canadezen en twee Italianen, telt de lijst één Fransman, één Litouwer, een Spanjaard, één Soedanees en één Tsjech) is het opleidingsniveau dat veel minder: 16 schrijvers behaalden een universitaire graad (over één auteur vonden we geen gegevens) en 12 van hen werden hoogleraar aan een universiteit. Hun competenties blijken tevens uit de rol die ze speelden op het internationale forum, zij het als adviseur van de secretaris-generaal van de VN (Francis Deng), als toonaangevend jurist bij het World Jewish Congress (Nehemiah Robinson), als Armeens onderminister van Buitenlandse Zaken en adviseur van de Armeense president (Gerard Libaridian) of als kardinaal en pauselijk gezant op het Eerste Vaticaans Concilie (Pietro Palazzini). Een ruime meerderheid (10 van de 16) volgde een studie in de rechten; telkens twee auteurs studeerden politieke wetenschappen of sociologie, één werd filosoof en één sinoloog. Gemiddeld waren de auteurs ouder dan $\mathbf{5 5}$ jaar op het ogenblik van publicatie - ze hadden dus al een zekere expertise in hun vakdomein opgebouwd. Ondanks die deskundigheid hebben heel wat auteurs zich toch geen blijvende plaats weten te veroveren in het zich ontwikkelende debat over genocide. Hun namen komen noch in de bibliografische overzichtswerken, noch in de bibliografieën van de standaardwerken over genocide aan bod. Geen van de auteurs wordt vermeld in Yvan Van Garsse's vroege bibliografische repertorium uit $1970^{1}$. In Israel Charny's bibliografische overzichtsstudie (1988) wordt enkel Berel Lang 3 keer in de lijst opgenomen (1 keer in het hoofdstuk over de 'Geschiedenis en Sociologie van Genocidale Moorden', en 2 keer in hoofdstuk 4, dat op de Holocaust als 'Ultieme en Archetypische Genocide' focust), en William O’Brien één keer (in het hoofdstuk over de 'Filosofie en Hedendaagse Gezichten van Genocide') ${ }^{2}$. In zijn recente sociologische studie over genocide (2007) voorzag ook Martin Shaw enkel

(1)Yvan Van Garsse, A bibliography of genocide, crimes against humanity and war crimes. Studiecentrum voor kriminologie en gerechtelijke geneeskunde, ed., Sint-Niklaas, 1970, 155 p.

(2) Israel Charny en Leo Kuper, Genocide. A critical bibliographic review. 2 vols, New York, Facts on file publisher, 1988 en 1991, p. 48, 78 en 184. 
een bescheiden plaats voor George Andreopoulos en William Schabas ${ }^{3}$. Daarnaast wordt niet één werk van de aangehaalde auteurs opgenomen in de omvangrijke bibliografische lijsten van Saul Friedländer (2007), Christopher Browning (2004), Shlomo Aronson (2004), Deborah Dwork en Robert-Jan Van Pelt (2002), Götz Aly (1995) of Martin Gilbert (1985)

Ook de taalkeuze zegt iets over de auteurs en de opties van hun uitgevers. Twee van de 35 geraadpleegde naslagwerken werden geschreven in het Spaans, drie in het Duits, telkens vier in het Italiaans en het Frans, acht in het Nederlands en 14 in het Engels. Plaatst men deze verhoudingen op een tijdslijn, dan ziet men dat de dominantie van het Engels als academische voertaal zich vooral vanaf de tweede helft van de jaren tachtig heeft doorgezet. Tien van de veertien Engelstalige encyclopedia dateren van na 1988, tegenover drie uit de periode 1970-1979 en één uit het tijdvak 1960-1969. Naslagwerken die zich op een specifieke, niet-Engelse regio focussen [zoals de Great Soviet Encyclopedia (1975), de Encyclopedia of Ukraine (1988), of de Encyclopedia of Africa south of the Sahara (1997)], namen al vrij snel het Engels aan als omgangstaal en bleven dat ook na 1980 doen. Dit weerspiegelt ongetwijfeld de politieke en algemeen culturele dominantie van de Verenigde Staten sinds de Tweede Wereldoorlog én de verwachting van de uitgevers dat het beoogde publiek het Engels in voldoende mate beheerst. Maar op die manier wordt alvast geen toegang gezocht tot de taalgroepen (zoals het Chinees, het Hindoestaans of het Spaans) die door hun pure omvang een plaats op het mondiale intellectuele forum verdienen.

Wat de auteurs van de artikelen betreft kunnen we dus besluiten dat ze ongeveer even vaak anoniem als met naam bekend zijn, dat ze doorgaans een hoge opleiding genoten (zij het vrij eenzijdig in de rechten), dat ze in hun taalkeuze bestaande politieke en culturele machtsverhoudingen reflecteren en dat de overgrote meerderheid geen blijvende rol van betekenis in het onderzoek naar genocide heeft gespeeld.

\section{GENOCIDE - OORSPRONG EN DEFINIËRING VAN DE TERM}

Hoewel de encyclopedie-artikelen onafhankelijk van elkaar totstand zijn gekomen, vertonen ze wat opbouw en inhoud betreft een gelijklopend patroon. Doorgaans opent het artikel met een korte omschrijving van het woord 'genocide', eventueel aangevuld met een etymologische duiding. Vervolgens wordt de ontstaansgeschiedenis van de

(3) Martin Shaw, What is genocide? Cambridge, Polity press, 2007, p 196 en 206.

(4) Saul Friedländer, Nazi Germany and the Jews (1939-1945). The years of extermination, New York, Harper Perennial, 2008 (1e hardcover druk 2007); Shlomo Aronson, Hitler, the Allies and the Jews, Cambridge, Cambridge University Press, 2004; Christopher Browning, The origins of the Final Solution. The evolution of Nazi Jewish policy, September 1939-March 1942, Londen, Random House Group publisher, 2004; Deborah Dwork, Robert-Jan Van Pelt, De Holocaust. Een geschiedenis, Amsterdam, Boom uitgeverij, 2002 (1e druk New York, 2002); Götz Aly, Final Solution. Nazi population policy and the murder of the European Jews, vertaling Belinda Cooper en Allison Brown, Londen, Arnold Publisher, 1999 (1e druk Frankfurt am Main, 1995); Martin Gilbert, The Holocaust. A history of the Jews of Europe during the Second World War, New York, Henry Holt and Company, 1985. 
betekenaar (het woord) en het betekende (het fenomeen waarnaar het woord verwijst) geschetst. In de regel diept de auteur de initiële, beknopte definitie dan verder uit en verwijst hij naar gerelateerde kwesties (zoals ratificatie van het genocideverdrag of de bestraffing van genocide). Verwijzend naar actuele kwesties worden in enkele uitzonderlijke gevallen tot slot een aantal kritische kanttekeningen gemaakt bij het besproken concept.

\section{De korte omschrijving}

De initiële, samengebalde definitie is van belang, omdat ze de eerste confrontatie van de lezer inhoudt met een bevattelijke, bondige en toegankelijke beschrijving van het gezochte lemma. Ze komt voor in 26 van de 35 encyclopedia (of 74,29\% van het totale aantal). Hoewel ze zo objectief mogelijk dient te zijn, is de omschrijving vaak sterk gekleurd door datgene wat de auteur zélf belangrijk vindt. Door de achtergrond van de schrijvers (vaak opgeleid in de rechten) én de afdwingbaarheid van de definitie in de Genocideconventie heeft de korte omschrijving een duidelijke juridische inslag. Vijftien van de 26 auteurs (57,69\%) die een korte definitie opnamen, verwijzen naar het Internationaal Militair Tribunaal, dat misdaden tegen de mensheid (waaronder genocide volgens de aanklacht ressorteerde) voor het eerst behandelde, beoordeelde en bestrafte ( 21 van de 35 auteurs verwijzen uitdrukkelijk naar het IMT). Tien auteurs halen het initiatief aan dat de Algemene Vergadering in 1946 ontwikkelde ter bestrijding van genocide; 30 van de 35 auteurs en 23 van de 26 auteurs die een korte definitie opnamen beroepen zich voor hun definitie op resolutie 260 (III)A van de Algemene Vergadering ('Conventie betreffende het voorkomen en bestraffen van de misdaad genocide,' kortweg aangeduid als 'Genocideconventie') van 9 december 1948. Bijkomende bronnen zijn zeldzaam, en indien ze voorkomen hebben ze telkens een manifest juridisch karakter: het gaat om de Nürnberger Nachfolgeprozesse (de 12 processen die in Neurenberg door de Amerikaanse autoriteiten werden gevoerd tegen hoofdorganen van het voormalige Derde Rijk), het proces in Tokyo of het proces tegen Adolf Eichmann in Jeruzalem. Die eenzijdige benadering wekt de indruk dat genocide een uitsluitend juridisch gegeven is, houdt geen rekening met de historische, sociologische of antropologische benaderingen die zich na de Tweede Wereldoorlog hebben ontwikkeld, en negeert het feit dat een aantal sociale wetenschappers de juridische definitie als ronduit ontoereikend hebben getypeerd. "Ik ken geen enkele ernstige academicus die deze definitie [uit de Genocideconventie] aanvaardt," merkte de gerenommeerde historicus en voormalige directeur van Yad Vashem, Yehuda Bauer op, in een persoonlijke reflectie over het actuele holocaustonderzoek. "Ze is inderdaad erg onbevredigend." ${ }^{5}$

Bovendien wordt voor de korte definitie vaak erg creatief omgesprongen met de exacte bewoordingen uit de Genocideconventie. Artikel 2 van het verdrag omschrijft

(5) Yehuda Bauer, "Holocaust research - a personal statement.", in The Holocaust. Voices of scholars, Centre for Holocaust Studies, Jagiellonian University, Auschwitz-Birkenau State Museum, eds. Krakow, 2009, 297 p. (p. 19-29, citaat p. 21). 
genocide als dié handelingen (vijf categorieën worden opgesomd), die begaan werden met de intentie om een nationale, etnische, raciale of religieuze groep als dusdanig, geheel of gedeeltelijk, uit te roeien. Over de 'mens rea' (de criminele intentie) als wezenlijk onderdeel van genocide, bestaat onder academici en in de rechtspraak een quasi absolute consensus. Toch vermelden 15 van de 26 auteurs (57,69\%) dit criminele opzet niet in hun korte definitie. De vier beschermde groepen zijn uitdrukkelijk in de conventieopgenomen. Toch geven 16 van de 26 auteurs (61,54\%) die groepen niet correct weer. Twee auteurs hebben het over vijf beschermde groepen (de Gran Enciclopedia Rialp heeft de nationale groep laten vallen en vervangen door een linguïstische en politieke groep; Meyers beschouwt ook 'sociale groepen' als beschermde entiteiten) en zeven auteurs gewagen van drie groepen. Op de Encyclopaedia Americana na, die 'etnische, raciale en nationale' groepen aanhaalt, vermelden alle encyclopedia de raciale en religieuze groepen, terwijl ze de etnische en nationale groep schijnbaar als inwisselbare begrippen beschouwen. Dié worden bijwijlen ook met de term 'völkisch' of 'politiek' aangeduid. De New Catholic Encyclopedia (1967) heeft het onnauwkeurig over 'politieke', 'raciale', 'of andere groepen', de Dictionnaire Encyclopédique ten onrechte over 'sociale of raciale' groepen. De Encyclopaedia Judaica vermeldt uitsluitend de etnische groepen, terwijl de Encyclopaedia Universalis het generaliserend op 'volledige mensengroepen' houdt. Over het (absolute of relatieve) aantal slachtoffers dat moet gevallen zijn om van volkerenmoord te kunnen spreken zegt de conventie niets; toch stelt ze expliciet dat ook de partiële uitroeiing van een beschermde groep als genocide kan gelden. Slechts iets meer dan een kwart van de auteurs (26,92 \%) vermeldt deze mogelijkheid. De uitdrukking 'als dusdanig' ('as such') lijkt onopvallend, maar heeft een grote betekenis. Ze verwijst naar het feit dat genocide de vernietiging van de groep beoogt - dat de dader met andere woorden primair op de liquidatie van een onderscheiden entiteit mikt, en niet op de diefstal van haar materiële rijkdom of de verovering van haar grondgebied. Toch nemen slechts twee van de 26 auteurs die belangrijke uitdrukking in hun korte definitie op. Tot slot verwijst de Conventie niet naar het planmatige karakter van de misdaad. Hoewel sommige rechtsspecialisten aannemen dat de drafters dit als een evidentie beschouwden en daarom niet in de Conventie hebben laten opnemen, weigerde het International Criminal Tribunal for the Former Yugoslavia die interpretatie na 2001 te volgen: het bestaan van een plan maakt geen wettelijk bestanddeel uit van de misdaad ${ }^{6}$. Drie auteurs (die hun artikel alle drie lieten publiceren na de uitspraak van het Hof) vermeldden echter nog steeds de vereiste van het geplande, systematische karakter van genocide.

(6) “Prosecutor versus Jelisić," cf. http://www.icty.org/x/cases/jelisic/acjug/en/jel-aj010705.pdf (origineel p. 18), William Schabas, "Was genocide committed in Bosnia and Herzegovina? First judgments of the international criminal tribunal for the former Yugoslavia", in William Schabas, War crimes and human rights. Essays on the death penalty, justice and accountability, Londen, 2008, 1158 p. (p. 663-688); Antonio Cassese, "Is genocidal policy a requirement for the crime of genocide," in Paolo Gaeta, The UN Genocide Convention. A commentary, Oxford, Oxford University Press, p. 128-136; voor het finale oordeel van het Hof, "The prosecutor versus Vujadin Popović et al," 10 juni 2010, cf. http://www.icty.org/x/cases/popovic/tjug/en/100610judgement.pdf (origineel p. 335-336). 
Tabel 2: De korte omschrijving.

\section{Encyclopedie (chronologisch)}

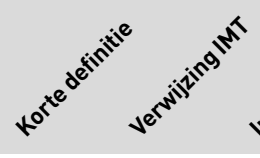

Janssens, L. DKE (1951)

Palazzini, Pietro. EC (1951)

\begin{tabular}{llllll}
+ & + & 0 & 0 & 0 & 0 \\
\hline+ & + & 0 & 0 & 0 & 0 \\
+ & 0 & 0 & 0 & 0 & 0 \\
+ & + & 0 & 0 & 0 & 0
\end{tabular}

Anoniem, DEI (1956)

Anoniem, OE (1961)

Anoniem, GLE (1962)

O'Brien, William, NCE (1967)

$+\quad 0$

Anoniem, SE (1968)

Anoniem, DEQ (1969)

Robinson, N. EJ (1971)

Anoniem, EL (1972)

De La Pradelle, Paul. LGLE (1974)

Anoniem, DEA (1974).

Anoniem, GSE (1975)

Anoniem, EE (1977)

Anoniem, DGO (1978)

Anoniem, MEL (1979)

Anoniem, GWPE (1980)

Ortego Costales, J. GER (1984)

Anoniem, EoU (1988)

Anoniem, GWPE (1991)

Deng, F. EASS (1997)

$+\quad 0$

$++$

$0 \quad 0$

$+\quad 0 \quad 0$

$+\quad 0$

$0++$

Allcock, J. CFYE (1998)

Lang, B. EEth (2001)

Vasak, Karel. EU (2002)

$+\quad 0+$

$\begin{array}{llllll}+ & 0 & + & 0 & 0 & 0 \\ + & + & 0 & 0 & 0 & 0\end{array}$

Brannigan en Cassis ECP (2002)

Anoniem, EHol (2003)

Greppi, Edouardo. L'EN (2003)

Libaridian, Gerard. ERH (2004)

Andreopoulos, G. TNEC (2005)

Welch, Claude. EA (2006)

Anoniem, BE (2006)

Robinson, Nehemiah. EJ (2007)

Bronkhorst, Daan. EM (2007)

Schabas, W. EHR (2009)

$\begin{array}{llllll}+ & + & 0 & 0 & 0 & 0 \\ + & + & 0 & + & 0 & 0 \\ + & 0 & + & + & 0 & +\end{array}$

2

7


De korte definitie schiet dus op minstens twee punten tekort: enerzijds door de eenzijdige juridische omschrijving, anderzijds door het toevoegen, weglaten of vervormen van passages uit de definitie die in de Genocideconventie wordt gehanteerd. Dit heeft grote implicaties. Want als de juridische definitie als dominante omschrijving wordt aanvaard, komen een aantal punten van debat niet meer aan bod. Zo'n punt is de kwestie van de 'uniciteit' van de Shoah. Omdat de preambule van de Conventie genocide erg ruim definieert, en bovendien expliciet aangeeft dat 'genocide in alle historische periodes grote verliezen aan de mensheid heeft toegebracht', ontstaat de indruk dat de naam 'genocide' laattijdig werd toegekend aan een reeds eeuwenlang bestaand fenomeen. Dit gaat in tegen de opvatting dat de jodenuitroeiing een historische gebeurtenis zonder precedent was, waarvoor absoluut een nieuwe term noodzakelijk was. Dit verschil in visie komt dan ook in de encyclopedia tot uiting. Daar waar achttien auteurs zich niet uitlaten over het (vermeende) ongeziene karakter van de Shoah, stellen elf schrijvers dat volkerenmoord een fenomeen van alle tijden is. Sommige auteurs doen dat erg expliciet. "De bekendste genocide van de $20^{\text {ste }}$ eeuw is de 'holocaust', de moord op Europese joden door nazi-Duitsland, maar daarvoor en daarna zijn er vele gevallen van genocide geweest," stelt Daan Bronkhorst in de Encyclopedie van de menselijkheid. "Ook al in de Oudheid en de Middeleeuwen kwam het tot gedeeltelijke of volledige uitroeiing van bevolkingsgroepen of raciale of religieuze groepen,” meldt de Brockhaus Enzyklopädie. "Genocides lijken vaak voorgekomen te hebben in de oude tijden," schrijft Claude Welch in de Encyclopedia Americana. Genocide was een "woord dat na de Tweede Wereldoorlog werd gelanceerd om een fenomeen aan te duiden dat niet nieuw was" (Libraridian, Encyclopedia of Russian History), een "term van recente origine" voor praktijken die "doorheen de geschiedenis" (Andreopoulos, The New Encyclopaedia Britannica) "steeds opnieuw" (Brannigan en Cassis, Encyclopaedia of Crime and Punishment) werden toegepast. Andere auteurs claimen niet met nadruk dat volkerenmoord een spoor doorheen de hele geschiedenis heeft getrokken, maar maken dit punt toch duidelijk door voorbeelden uit een ver verleden (zie onder meer Palazzino in de Encyclopedia Cattolica of de anonieme auteur van de Dictionnaire encyclopédique Quillet). Daartegenover staan zes schrijvers die in de moord op de Europese Joden een duidelijke breuklijn menen te zien. "De vroege geschiedenis levert voorbeelden van uitroeiingsoorlogen en systematische verdrukking van onderworpen volkeren," schrijft William O'Brien in de 'New Catholic Encyclopedia'. "Zelfs in de moderne tijden zijn er ogenblikken van intense raciale vervolging geweest, zoals die van de Armeniërs in het Ottomaanse Rijk, maar niets dat vergelijkbaar is met het beleid van grootschalige moord en vervolging van minderheidsgroepen, dat van 1933 tot 1945 door het Hitler regime in Duitsland werd gevoerd.” Nehemiah Robinson (Encyclopaedia Judaica) trad hem bij: "Hoewel in de geschiedenis van de mensheid al meerdere massaliquidaties waren voorgekomen, had geen enkele de omvang en de planning gekend van de slachting van de Europese joden door het Derde Rijk." En ook Karel Vasak (Encyclopaedia Universalis) meende dat massaslachting de hele mensheid had getekend, "maar nooit met de omvang" van die van het nationaalsocialistische regime. Indien dus al een onderscheid wordt gemaakt tussen de judeocide en ander 
massaal dodelijk geweld, dan gebeurt dit uitsluitend in kwantitatieve termen (de omvang). Op een eventueel ontisch onderscheid (een verschil in 'zijn', in karakter) gaat geen enkele auteur in. Nochtans is de vraag naar het vernieuwende karakter van de Shoah in het wetenschappelijke debat verre van uitgeklaard?

Omdat de ruime definitie van de Genocideconventie toestaat volkerenmoorden te herkennen doorheen de hele geschiedenis, halen de auteurs daarenboven voorbeelden van 'genocides' aan die intrinsiek sterk van elkaar verschillen en ongetwijfeld aanzienlijk afwijken van hetgene wat heel wat vakspecialisten onder genocide begrijpen. Acht auteurs halen geen enkel voorbeeld aan; in drie artikelen wordt enkel naar vaag omschreven groepen verwezen: "bepaalde bevolkingsgroepen" (Grote Oosthoek), "minderheidsgroepen" (New Catholic Encyclopaedia) of "leden van groepen die als inferieur werden beschouwd” (La Grande Encyclopédie Larousse). De overige auteurs halen 49 onderscheiden groepen aan, die ooit het slachtoffer zouden zijn geworden van genocide. De grootste consensus bestaat daarbij over de uitroeiing van de Europese Joden: 23 van de 24 auteurs (95,83\%) die naar een concrete groep verwijzen ter illustratie, vermelden daarbij de Shoah. Elf schrijvers geven de massamoord op de Armeniërs tijdens de Eerste Wereldoorlog als voorbeeld, tien verwijzen naar exJoegoslavië (5 auteurs hebben het in het over 'Joegoslavië' zonder meer, telkens 2 over 'Bosnië' en 'Kroatië' en 1 auteur vermeldt het massale doden van de moslims door Kroaten en Serviërs samen), 8 naar de Hutu's en Tutsi's, 7 naar de genocide op de zigeuners tijdens de Tweede Wereldoorlog, 6 naar de Tsjetsjenen, 5 naar de Romeinen (omwille van de verwoesting van Carthago en Jeruzalem) en de Ibo (Nigeria), en telkens 4 naar de 'native Americans' (door de koloniale mogendheden), de Oekraïners (door de Sovjet-Unie), de Cambodjanen (onder de Rode Khmer) en de Koerden (door het Iraakse regime van Saddam Hoessein).

\section{Het ontstaan van het begrip 'genocide'}

Het woord 'genocide' is een samentrekking van het Griekse woord 'genos' (geslacht/soort) en het Latijnse 'caedere' (wat 'doden' betekent). Hoewel de etymologie van nieuwe termen heel wat licht kan werpen op de wijze waarop ze door de eerste gebruikers werden begrepen, wordt de herkomst van het concept genocide in het merendeel van de geraadpleegde encyclopedia (22 van de 35, of 62,85\%) niet vermeld. Bovendien wordt Raphael Lemkin, de jurist die doorgaans als bedenker van het concept genocide wordt aangeduid, in meer dan de helft van de encyclopedia (18, of 51,43\%) niet vernoemd. Wanneer dit wél gebeurt, krijgt de lezer heel wat tegenstrijdige informatie mee. Zo zijn de biografische gegevens vaak erg onzorgvuldig. De Grande Encyclopédie Larousse meldt dat Lemkin in Vilnius (hoofdstad van het huidige Litouwen) werd geboren; acht encyclopedia noemen hem een 'Poolse' jurist, twee omschrijven hem als een Amerikaan. Lemkin werd echter geboren in het Wolkowysk district, dat in die tijd tot het Russische rijk behoorde (Polen bestond in 1900 al meer dan

(7) Voor een overzicht van het debat, zie: Alan Rosenbaum, ed. Is the Holocaust unique? Perspectives on comparative genocide, Westview Press, Boulder, 2009, 359 p. 
een eeuw niet meer), en dat vandaag deel uitmaakt van de staat Wit-Rusland. Pas in april 1941 betrad hij het Amerikaanse grondgebied. Drie naslagwerken noemen hem een advocaat; de Encyclopedie van de Holocaust omschrijft hem als een rechter. Lemkin had daadwerkelijk rechten gestudeerd, maar werkte na zijn studies meteen als assistent openbaar aanklager en later als openbaar aanklager, vanaf de tweede helft van de jaren twintig. Rechter is hij nooit geweest. Ook het eerste gebruik van de term genocide wordt in de encyclopedia vaak onnauwkeurig weergegeven. De Dizionario enciclopedico Italiano meldt dat de term geïntroduceerd was 'door de Amerikaanse professor Lemkin in 1946, in de tijd van het proces van Neurenberg'; ook de New Catholic Encyclopedia en de Encylopedia of Russian History situeren het begin van het begrip 'na de oorlog', 'in de tijd dat de nazi's werden berecht'. In werkelijkheid kwam de term al voor in het boek dat Lemkin in 1944 publiceerde, en dat door Nehemiah Robinson (1971) ten onrechte 'Axis Rule in Europe' wordt genoemd - een fout die in de editie van 2007 nog steeds niet was rechtgezet (de correcte titel luidt: 'Axis rule in occupied Europe. Laws of occupation, analysis of government, proposals for redress'; het boek werd in 1944 uitgegeven door Columbia University Press in New York). De Encyclopedie van de Holocaust deelt de lezer mee dat Lemkin de term genocide voor het eerst gebruikte tijdens een conferentie in Madrid in 1933. Augustine Brannigan en Viola Cassis suggereren dat het concept in 1933 tot stand kwam ten gevolge van 'de opkomst van de nazi's en hun ontwikkeling en implementatie van het plan om de Europese joden uit te moorden' (p. 769). Maar in 1933 gebruikte Lemkin enkel het begrip 'barbarisme', dat nooit een wijde verspreiding zou kennen; daarenboven is de aanname dat de plannen voor genocide al in 1933 werden ontwikkeld en uitgevoerd op zijn minst erg problematisch.

\section{Het corpus van het artikel}

In het hoofdbestanddeel van het artikel wordt het concept 'genocide' vervolgens verder uitgewerkt. Opnieuw heeft de juridische benadering daarbij het overwicht, zij het dat bepaalde elementen sterk in de verf worden gezet, terwijl andere enkel in de marge worden opgemerkt. De 19 artikelen van 'Conventie over de preventie en de bestraffing van de misdaad genocide' vallen in feite uiteen in twee delen. In de eerste negen artikelen worden verschillende elementen van een definitie aangeraakt; artikel 10 tot en met 19 handelen daarentegen over de wijze waarop het verdrag in de toekomst moet of kan worden geïmplementeerd. Dat het tweede, technische luik minder aan bod komt in een beknopt overzichtsartikel is begrijpelijk. Maar zelfs over het gewicht van het eerste deel zijn lang niet alle auteurs het eens. In tweëntwintig bijdragen $(62,86 \%)$ wordt artikel 2 van de genocideconventie, dat de daden die als genocidaal getypeerd kunnen worden opsomt, geheel of gedeeltelijk overgenomen. Maar slechts 8 auteurs (22,86 \%) wijzen erop, dat volgens artikel 3 niet enkel het uitvoeren, maar ook medeplichtigheid, samenzwering, aanzetten tot en een poging ondernemen om een genocide uit te voeren vervolgbare handelingen zijn. Terwijl bijna de helft (16, of $45,71 \%$ ) van de schrijvers aangeeft dat voor de bestraffing van genocide een op te richten internationaal strafhof of een nationale rechtbank bevoegd 
Tabel 3: Het corpus.

\begin{tabular}{|c|c|c|c|c|c|c|}
\hline Encyclopedie (chronologisch) & Art. 2-3 & Art. 4 & Art. 5 & Art. 6 & Art. 7 & Art. 8-9 \\
\hline Janssens, L. DKE (1951) & 1 & 1 & 1 & 1 & 1 & 0 \\
\hline Palazzini, Pietro. EC (1951) & 1 & 0 & 0 & 0 & 0 & 0 \\
\hline Anoniem, DGH (1953) & 0 & 0 & 0 & 0 & 0 & 0 \\
\hline Anoniem, DEl (1956) & 0 & 1 & 0 & 1 & 0 & 0 \\
\hline Anoniem, OE (1961) & 0 & 1 & 1 & 1 & 0 & 0 \\
\hline Anoniem, GLE (1962) & 0 & 0 & 0 & 0 & 0 & 0 \\
\hline O’Brien, William, NCE (1967) & 0 & 0 & 1 & 1 & 0 & 1 \\
\hline Anoniem, SE (1968) & 0 & 1 & 0 & 1 & 0 & 0 \\
\hline Anoniem, DEQ (1969) & 0 & 0 & 0 & 0 & 0 & 0 \\
\hline Robinson, N. EJ (1971) & 1 & 1 & 0 & 1 & 0 & 1 \\
\hline Anoniem, EL (1972) & 1 & 0 & 0 & 0 & 1 & 1 \\
\hline De La Pradelle, Paul. LGLE (1974) & 1 & 1 & 1 & 0 & 1 & 0 \\
\hline Anoniem, DEA (1974). & 1 & 0 & 0 & 0 & 0 & 0 \\
\hline Anoniem, GSE (1975) & 1 & 0 & 0 & 0 & 0 & 0 \\
\hline Anoniem, EE (1977) & 1 & 0 & 1 & 0 & 0 & 1 \\
\hline Anoniem, DGO (1978) & 0 & 0 & 0 & 0 & 0 & 0 \\
\hline Anoniem, MEL (1979) & 0 & 0 & 0 & 0 & 1 & 0 \\
\hline Anoniem, GWPE (1980) & 0 & 0 & 0 & 1 & 0 & 0 \\
\hline Ortego Costales, J. GER (1984) & 1 & 0 & 0 & 0 & 0 & 0 \\
\hline Anoniem, EoU (1988) & 0 & 0 & 0 & 0 & 0 & 0 \\
\hline Anoniem, GWPE (1991) & 0 & 0 & 0 & 1 & 0 & 0 \\
\hline Deng, F. EASS (1997) & 0 & 0 & 0 & 0 & 0 & 0 \\
\hline Allcock, J. CFYE (1998) & 1 & 0 & 0 & 0 & 0 & 0 \\
\hline Lang, B. EEth (2001) & 1 & 1 & 0 & 0 & 0 & 0 \\
\hline Vasak, Karel. EU (2002) & 1 & 1 & 0 & 0 & 1 & 0 \\
\hline Brannigan en Cassis ECP (2002) & 1 & 1 & 1 & 1 & 1 & 1 \\
\hline Anoniem, EHol (2003) & 1 & 0 & 0 & 0 & 0 & 0 \\
\hline Greppi, Edouardo. L’EN (2003) & 1 & 1 & 1 & 1 & 1 & 1 \\
\hline Libaridian, Gerard. ERH (2004) & 1 & 0 & 0 & 1 & 0 & 0 \\
\hline Andreopoulos, G. TNEC (2005) & 1 & 1 & 0 & 1 & 0 & 1 \\
\hline Welch, Claude. EA (2006) & 1 & 0 & 1 & 1 & 0 & 0 \\
\hline Anoniem, BE (2006) & 1 & 0 & 1 & 0 & 0 & 0 \\
\hline Robinson, Nehemiah. EJ (2007) & 1 & 1 & 0 & 1 & 0 & 1 \\
\hline Bronkhorst, Daan. EM (2007) & 1 & 0 & 0 & 1 & 0 & 1 \\
\hline Schabas, W. EHR (2009) & 1 & 1 & 1 & 1 & 1 & 1 \\
\hline Totaal & 22 & 13 & 10 & 16 & 8 & 10 \\
\hline
\end{tabular}


zijn, merken slechts dertien auteurs (37,14 \%) in het corpus van het artikel op dat niet enkel verantwoordelijke beleidslui, maar ook ambtenaren en private personen voor genocide vervolgd kunnen worden (artikel 4), en geeft minder dan één op drie (10 auteurs, of 28,57\%) aan dat staten de nodige stappen moeten ondernemen om de conventie in de nationale wetten te laten opnemen (zoals artikel 5 voorschrijft). Dat volkerenmoord geen politiek misdrijf is en daarom de uitlevering van een verdachte niet in de weg kan staan, wordt slechts door 8 van de 35 auteurs als vermeldenswaard beschouwd, en dat staten beroep kunnen doen op een $\mathrm{VN}$-orgaan voor de preventie van genocide en het Internationaal Gerechtshof in geval van betwisting een finaal oordeel zal vellen (artikelen 8 en 9) wordt slechts door 10 auteurs opgemerkt.

De meerderheid van de auteurs (19 van de 35, of 54,29\%) geeft meer uitleg over de ondertekening of de ratificatie van het verdrag. Daaruit blijkt een zekere verontwaardiging over de hardnekkigheid van enkele grote staten (waaronder de VSA, China en de Sovjet-Unie) om niet - of zeer laattijdig - te ratificeren. Dat zijn acht auteurs voor de VSA (de Encyclopedia of crimes and punishment vermeldt 1989 als jaar van ratificatie, de Encyclopaedia of Ethics het jaar 1988 - het verdrag werd door president Ronald Reagan ter ratificatie ondertekend op 4 november 1988), waarbij twee auteurs (van de Encyclopedia of Ethics en de Encyclopedia Americana) erop wijzen dat de talrijke voorbehouden van de Verenigde Staten de slagkracht van de conventie in ruime mate hebben aangetast. Hoewel China het verdrag in juli 1949 ondertekende en in april 1983 ratificeerde, vermeldt de Encyclopedia Universalis in de editie van 2002 ten onrechte dat de conventie in China nog steeds niet van kracht is ('Sans parler de la Chine communiste, toujours absente'); de GWPE paste de opmerking dat 'de Chinese Volksrepubliek nog geen partij [is] bij het verdrag' (1980) in de geactualiseerde uitgave van 1991 wél correct aan: 'De Sovjet-Unie is tot ratificatie overgegaan onder het genoemde voorbehoud'. In telkens één encyclopedie werd op de niet-deelname van Congo, België (Grande Encyclopédie Larousse) en Zuid-Afrika (Meyers Enzyklopädisches Lexikon) gewezen. Acht auteurs maken er de lezer attent op dat tot op het ogenblik van publicatie van het artikel nog geen internationale rechtbank werd opgericht die zou kunnen instaan voor de berechting van genocide; 5 auteurs hekelen de laattijdige oprichting; in 21 artikelen wordt er helemaal niets over gezegd; en in één wordt ten onrechte gesteld dat er nog geen tribunaal bestaat, terwijl ze in werkelijkheid wél al was opgericht.

Lemkins definitie van genocide was erg ruim. Ze omvatte niet enkel de fysieke uitroeiing van erg uiteenlopende groepen maar omhelsde ook de vernietiging van culturen, waardoor de identiteit van een bepaalde groep zou ophouden te bestaan. Hoeweldegenocideconventiehet concept veel strikter afbakende, heeft het International Criminal Tribunal for the Former Yugoslavia (ICTFY) bepaald dat volkerenmoord niet per se op moord hoeft te slaan (ook verkrachting kan genocidaal zijn, als ze plaatsvindt met de intentie een beschermde bevolkingsgroep te vernietigen). Hoe genocide en volkeren-moord synoniemen zouden kunnen zijn (zoals de Brockhaus Enzyklopädie 
aangeeft), indien er bij genocide geen sprake van moord moet zijn, is niet helemaal duidelijk. In ieder geval geven drie encyclopedia aan dat genocide enkel betrekking heeft op 'fysieke vernietiging', terwijl één encyclopedie-auteur uitdrukkelijk stelt dat genocide niét enkel op fysieke vernietiging slaat en één auteur veiligheidshalve aangeeft dat het 'vooral' om fysieke vernietiging gaat.

Bovendien is genocide geen 'act of state'. Dit betekent dat een staat zich niet kan beroepen op soevereiniteit en op het principe dat de ene staat zich niet in de interne kwesties van een andere staat mag mengen. Slechts drie van de 35 auteurs $(8,57 \%)$ vermelden dit belangrijke juridische beginsel. Dezelfde drie auteurs geven aan dat de dader van genocide zich niet op gehoorzaamheid en de bevelen van superieuren kan beroepen. Andere belangrijke beginselen (het probleem van de verjaring, de moeilijkheid om 'aanzetten tot genocide' te bewijzen, de verantwoordelijkheid van niet-statelijke actoren) worden slechts sporadisch en in de marge opgemerkt.

\section{DE BIBLIOGRAFIEËN}

De betrouwbaarheid van de encyclopedieartikelen neemt toe naarmate de lezer in staat is de informatiebronnen van de auteur op te sporen, om zich van de inhoud en kwaliteit ervan te kunnen vergewissen. In de regel zijn de geraadpleegde werken daarom in een korte bibliografische lijst (in afwijkende typografie, onderaan het artikel), opgenomen. Toch zijn deze bibliografieën in heel wat encyclopedieën niet terug te vinden: in 14 van de 35 geraadpleegde naslagwerken (40 \%) wordt niet één geraadpleegde studie aan de lezer voorgelegd. In de overige 21 encyclopedia is de lengte van de bibliografie erg variabel, van één tot zeventien geraadpleegde studies, met een gemiddelde van 4,31 werken per encyclopedie.

Aan de hand van de bibliografie kan de lezer tevens doorverwezen worden naar betrouwbare, uitgebreide en gespecialiseerde standaardwerken. Er lijkt echter geen consensus te bestaan over één of meerdere referentiewerken die bij uitstek voor diepgaander analyse van het concept genocide in aanmerking komen. Dit blijkt onder meer uit de grote diversiteit van de vermelde auteurs. In totaal komen in de 35 bestudeerde encyclopedia 111 studies van 97 verschillende auteurs voor. Maar 87 studies (78,38 \%) worden slechts één keer vermeld. Daarenboven is het hoogst uitzonderlijk dat van één onderzoeker meerdere werken uit zijn wetenschappelijke oeuvre worden vermeld. Die eer valt enkel Israel Charny (waarvan 3 monografieën en één artikel worden geciteerd), Raphael Lemkin (1 monografie en twee artikelen), Norbert Elias (2 monografieën en één artikel), Robert Conquest (twee monografieën), en H. Fein, L. Kuper, S. Lener, M. Levene en S. Power (telkens met twee studies) te beurt. Een relatieve overeenstemming bestaat enkel over de studie van de Nederlandse jurist Pieter Nicolaas Drost (die in 9 van de 35 encyclopedia wordt vermeld) en het werk van Nehemia Robinson ('The Genocide Convention' uit 1960, dat in zes naslagwerken wordt aangehaald).

Ook de aard van de gebruikte informatiebronnen is betekenisvol. Slechts twee (Franse) encyclopedia (met name La Grande Encyclopédie Larousse uit 1974 en de 
Encyclopaedia Universalis uit 2002) verwijzen in hun bibliografische lijsten naar een historische bron (de Genocideconventie van de VN uit 1948). Alle overige referenties betreffen historische studies. In de veronderstelling dat monografieën eerder beschouwend zijn, terwijl artikelen in tijdschriften en bundels de recentste en meest vernieuwende visies weergeven, merkt men een toegenomen interesse voor de beschouwende werken: daar waar de bibliografische lijsten in de jaren veertig 4 monografieën citeerden, waren dat er in de jaren '80 al elf en in de jaren 1990 achttien. Het aantal geciteerde tijdschriftartikelen nam daarentegen af van 7 (jaren 1940) naar 5 en 4 (jaren 1950 en 1960), om op één verwijzing te stagneren in de jaren 1990 en 2000.

Wat de origine van de geciteerde werken betreft stelt men een duidelijk overwicht van Amerikaanse studies vast. De helft van alle gebruikte of aangeprezen studies (59 op 118 publicatieplaatsen) werden (onder meer) in de Verenigde Staten uitgegeven; het Verenigd Koninkrijk neemt slechts een bescheiden tweede plaats in, met 15 studies (of $12,71 \%$ van het totaal), gevolgd door Duitsland (14 studies, of 11,86 \%) en Frankrijk (10 studies of 8,47\%). Al vanaf de jaren 1950 worden van geen enkel land méér werken in de bibliografische lijsten opgenomen dan van Amerika (uitsluitend in de jaren 1940 werd vaker naar Italiaanse studies verwezen dan naar Amerikaanse). Toch behield het geheel van Europese landen qua aangeprezen werken vier decennia lang het overwicht. Voor de jaren 1940 werden 9 Europese en 3 Amerikaanse werken aanbevolen, voor de jaren 195013 Europese en 7 Amerikaanse, en voor de jaren 1960 en 1970 telkens 6 Europese, tegenover respectievelijk 5 en 3 Amerikaanse studies. Pas in de jaren 1980 werd Amerika dominant: meer dan de helft van de geciteerde informatiebronnen waren in dat decennium Amerikaans (9 van de 14). Die voorsprong nam in de jaren 1990 nog toe (21 van de 28 aangehaalde werken waren toen Amerikaans) en hield in het volgende decennium aan (11 van de 15 werken). In verhouding tot het aandeel van de geciteerde werken per decennium, is het aantal vermelde Amerikaanse werken duidelijk overrepresentatief: daar waar ongeveer een kwart van de geciteerde werken uit de jaren negentig en 1/8 uit de jaren 2000 stamt, nemen de Amerikaanse werken respectievelijk 35,59 \% en 18,64 \% voor hun rekening. Dat was helemaal anders in de jaren 1940 en 1950, waaruit 11,71 en 17,12 \% van de geciteerde werken stamt. Toén bedroeg het aandeel van de Amerikaanse boeken slechts 5,08 en 11,86 \%.

\section{Algemeen besluit}

Wat het begrip 'genocide' betreft hebben encyclopedia niet de eenduidigheid en objectiviteit die er soms aan wordt toegeschreven. Dit betekent niet dat de auteurs in hun artikelen onoprecht of nalatig zouden zijn. Maar dat ze toonaangevende experts in hun vakdomein zouden zijn, kon door het voorliggende onderzoek niet worden bevestigd. Een welomlijnde menswetenschappelijke beschrijving komt in hun artikelen nauwelijks aan bod. De bijdragen zijn vaak gekleurd door de eenzijdige juridische benadering van het onderwerp. Los van de sporadische onjuistheden en contradicties, zorgt de exclusieve aandacht voor bepaalde onderdelen van de definitie (en de omissie van andere) eerder voor verwarring dan voor verheldering. Ook de 
bibliografieën geven geen helder antwoord op de vraag in welke studies men de meest gezagvolle informatie kan terugvinden. Of encyclopedia in de speurtocht naar objectieve gegevens voorrang verdienen op de meer moderne, digitale massamedia (zoals wikipedia), zou ons verder voeren dan de grenzen van dit onderzoek toelaten. Maar dat ook de naslagwerken de redactionele keuzes en de persoonlijke invalshoek van de auteur en het tijdsgewricht van zijn bijdrage weerspiegelen lijkt wat dit lemma betreft vrij onbetwistbaar.

\section{Bibliografie}

ALY, Götz. Final Solution. Nazi population policy and the murder of the European Jews ('1995, vertaling Belinda Cooper en Allison Brown) Arnold Publisher, Londen, 1999, 305 p.

ARONSON, Shlomo. Hitler, the Allies and the Jews. Cambridge University Press, Cambridge, $2004,382 \mathrm{p}$.

BAUER, Yehuda. "Holocaust research - a personal statement." In: The Holocaust. Voices of scholars. Centre for Holocaust Studies, Jagiellonian University, Auschwitz-Birkenau State Museum, eds. Krakow, 2009, 297 p. (in het bijzonder pp. 19-29).

BROWNING, Christopher. The origins of the Final Solution. The evolution of Nazi Jewish policy, September 1939-March 1942. Random House Group publisher, Londen, 2004, 615 p.

CASSESE, Antonio. "Is genocidal policy a requirement for the crime of genocide," In: The UN Genocide Convention. A commentary, Paolo Gaeta, ed. Oxford University Press, Oxford, 2009, 616 p. (in het bijzonder 128-136).

CHARNY, Israel en KUPER, Leo. Genocide. A critical bibliographic review. 2 vols. Facts on file publisher, New York, 1988 en 1991.

DWORK, Deborah en VAN PELT, Robert-Jan. De Holocaust. Een geschiedenis (2007, vertaling Coen Hilbrink) Boom uitgeverij, Amsterdam, 2002, 504 p.

FRIEDLAENDER, S. Nazi Germany and the Jews (1939-1945). The years of extermination (2007) Harper Perennial publisher, New York, 2008, 896 p..

GILBERT, Martin. The Holocaust. A history of the Jews of Europe during the Second World War. Henry Holt and Company, New York, 1985, 959 p.

ROSENBAUM, Alan., ed. Is the Holocaust unique? Perspectives on comparative genocide (2001) Westview Press, Boulder, 2009, 359 p.

SCHABAS, William. "Was genocide committed in Bosnia and Herzegovina? First judgments of the international criminal tribunal for the former Yugoslavia." In: War crimes and human rights. Essays on the death penalty, justice and accountability. W. Shabas, ed. Cameron May publisher, Londen, 2008, 1158 p. (in het bijzonder pp. 663-688);

SHAW, Martin. What is genocide? Polity press, Cambridge, 2007, 222 p.

VAN GARSSE, Yvan. A bibliography of genocide, crimes against humanity and war crimes. Studiecentrum voor kriminologie en gerechtelijke geneeskunde, ed., Sint-Niklaas, 1970, 155 p. 